Review

\title{
A review of bioceramics-based dental restorative materials
}

\author{
Abdul Samad KHAN ${ }^{1}$ and Mariam Raza SYED ${ }^{2,3}$ \\ ${ }^{1}$ Department of Restorative Dental Sciences, College of Dentistry, Imam Abdulrahman Bin Faisal University, Dammam 31441, Saudi Arabia \\ ${ }^{2}$ Department of Dental Materials, University of Health Sciences, Lahore 54000, Pakistan \\ ${ }^{3}$ Department of Dental Materials, Lahore Medical and Dental College, Lahore 54000, Pakistan \\ Corresponding author, Abdul Samad KHAN; E-mail: akhan@iau.edu.sa
}

\begin{abstract}
Currently, much has been published related to conventional resin-based composites and adhesives; however, little information is available about bioceramics-based restorative materials. The aim was to structure this topic into its component parts and to highlight the translational research that has been conducted up to the present time. A literature search was done from indexed journals up to September 2017. The main search terms used were based on dental resin-based composites, dental adhesives along with bioactive glass and the calcium phosphate family. The results showed that in 123 articles, amorphous calcium phosphate (39.83\%), hydroxyapatite $(23.5 \%)$, bioactive glass $(16.2 \%)$, dicalcium phosphate $(5.69 \%)$, monocalcium phosphate monohydrate $(3.25 \%)$, and tricalcium phosphate $(2.43 \%)$ have been used in restorative materials. Moreover, seven studies were found related to a newly developed commercial bioactive composite. The utilization of bioactive materials for tooth restorations can promote remineralization and a durable seal of the tooth-material interface.
\end{abstract}

Keywords: Bioceramics, Dental adhesives, Dental composites, Calcium phosphates, Bioactive glass

\section{INTRODUCTION}

The ultimate research goal for restoration of tooth structure depends upon the use of durable, bondable and aesthetically acceptable material ${ }^{1)}$. The efforts to develop ideal materials with better properties continue at a rapid pace. The main component of the tooth is a carbonated hydroxyapatite (HA) that contains other ions such as fluorine, chlorine, sodium etc. ${ }^{2}$. Therefore, the key strategy to combat diseased teeth is to restore the damaged structure and to promote remineralization by means of a biomimetic approach ${ }^{3)}$.

Synthetic calcium phosphate (CP) materials consist of an inorganic phase and are mainly based on amorphous calcium phosphate (ACP), HA $\left(\mathrm{Ca}_{10}\left(\mathrm{PO}_{4}\right)_{6}(\mathrm{OH})_{2}\right)$, tetracalcium phosphate [TTCP, $\left.\left(\mathrm{Ca}_{4}\left(\mathrm{PO}_{4}\right)_{2} \mathrm{O}\right)\right]$, monocalcium phosphate monohydrate [MCPM, $\left.\left(\mathrm{Ca}\left(\mathrm{H}_{2} \mathrm{PO}_{4}\right)_{2} \cdot \mathrm{H}_{2} \mathrm{O}\right)\right]$, $\beta$-tricalcium phosphate $\left[\beta\right.$-TCP, $\left.\left(\beta-\mathrm{Ca}_{3}\left(\mathrm{PO}_{4}\right)_{2}\right)\right], \alpha$-tricalcium phosphate $[\alpha$-TCP, $\left.\left(\alpha-\mathrm{Ca}_{3}\left(\mathrm{PO}_{4}\right)_{2}\right)\right]$ and octacalcium phosphate [OCP, $\left(\mathrm{Ca}_{8} \mathrm{H}_{2}\left(\mathrm{PO}_{4}\right)_{6} .5 \mathrm{H}_{2} \mathrm{O}\right]^{4}$. Bioactive glass (BAG) is another type of bioceramic, which has gained popularity since its invention in 1969 by Prof. Hench. It consists mainly of silicon, calcium, sodium, phosphorous, and oxygen ${ }^{5}$. These biomaterials have extensively been used in bone repair, tissue regeneration, coatings, drug delivery devices, and tumour treatment ${ }^{6,7)}$.

The present trend in dentistry is to utilize new restorative materials to make dentistry more comfortable, durable, efficient and esthetically pleasing for the patient. Therefore, resin-based composites with bioactive remineralizing agents are in huge demand nowadays. Bioactive fillers are incorporated in the resin matrix of composite restorations and in vitro studies have showed a sustained release of supersaturated ions of calcium and phosphate ${ }^{8,9)}$. The $\mathrm{CP}$ composites have been shown to remineralize enamel and dentin lesions in vitro ${ }^{10)}$. These bioactive fillers can bond with the living tissue chemically by forming CP layer at the toothmaterial interface that renders the restoration durable and prevents it from bacterial ingression ${ }^{11)}$.

It is desirable that dental restorative materials should be bioactive which can improve the mechanical properties and bond strength, depending upon the dissolution behavior of ions from the surface and to have a microstructure morphology that can promote the toughening mechanisms of crack deflection and bridging ${ }^{12}$. However, it is still not clear, which bioactive material should be incorporated in dental resins so as to fulfill this requirement of restorative materials, relevant to the oral environment. The authors did not find an exclusive review paper that covers the main aspects of bioactive dental resin-based composites (RBC) and adhesives. Therefore, the aim of this review was to organize this issue into its component parts and to provide evidence-based principles that are sound from a dental restorative perspective.

\section{METHODS}

The initial review began with a MEDLINE/PubMed, Scopus, Web of Science and Google Scholar search with laboratory and clinical trial findings. The structured search protocol adopted for the search is given in Table 1.

Color figures can be viewed in the online issue, which is available at J-STAGE.

Received Feb 3, 2018: Accepted May 31, 2018

doi:10.4012/dmj.2018-039 JOI JST.JSTAGE/dmj/2018-039 
Table 1 Keywords used for PubMed search and number of articles found with initial search with these keywords

\begin{tabular}{|c|c|c|}
\hline Sr. \# & Keywords & $\begin{array}{l}\text { No. of Papers found } \\
\text { on PubMed }\end{array}$ \\
\hline 1 & Bioactive Dental Composite & 179 \\
\hline 2 & Dental Resin Composites AND Hydroxyapatite & 183 \\
\hline 3 & Dental Resin Adhesives AND Hydroxyapatite & 62 \\
\hline 4 & Dental Adhesive AND Hydroxyapatite & 476 \\
\hline 5 & Dental Resin Composite AND Calcium Phosphate & 321 \\
\hline 6 & Dental Composite AND Calcium Phosphate & 283 \\
\hline 7 & Dental Composite AND Amorphous Calcium Phosphate & 91 \\
\hline 8 & Dental Resin Composite AND Amorphous Calcium Phosphate & 82 \\
\hline 9 & Dental Adhesive AND Calcium Phosphate & 516 \\
\hline 10 & Dental Resin Adhesive AND Calcium Phosphate & 115 \\
\hline 11 & Dental Resin Adhesive AND Amorphous Calcium Phosphate & 57 \\
\hline 12 & Dental Resin Adhesive AND Tricalcium Phosphate & 10 \\
\hline 13 & Dental Adhesive AND Tricalcium Phosphate & 94 \\
\hline 14 & Dental Composite AND Tricalcium Phosphate & 110 \\
\hline 15 & Dental Resin Composite AND Tricalcium Phosphate & 72 \\
\hline 16 & Dental Resin Composite AND Bioactive Glass & 111 \\
\hline 17 & Dental Composite AND Bioactive Glass & 101 \\
\hline 18 & Dental Adhesive AND Bioactive Glass & 145 \\
\hline 19 & Dental Resin Adhesive AND Bioactive Glass & 32 \\
\hline 20 & Bioceramics AND Dental Adhesives & 9 \\
\hline 21 & Bioceramics AND Dental Resin Composites & 6 \\
\hline 22 & Bioceramics AND Dental Composites & 10 \\
\hline 23 & Bioactive Dental Composites AND Clinical Applications & 8 \\
\hline 24 & Bioactive Fillers AND Dental Composite & 21 \\
\hline 25 & Bioactive Fillers AND Dental Adhesive & 21 \\
\hline 26 & Activa Bioactive & 7 \\
\hline 27 & Activa Bioactive Restorative & 3 \\
\hline
\end{tabular}

\section{Study selection}

The search of the literature was performed without any restriction on a date and was done up to September 2017. Full texts of papers were obtained from the journals and the inclusion criteria for articles were;

(1) bioceramics (i.e. BAG, HA, ACP, dicalcium phosphate (DCP), OCP, tricalcium phosphate (TCP), TTCP and MCPM) based dental restorative materials including adhesives and filling materials (denoted as composite in this article)

(2) laboratory based analysis, in-vitro and in-vivo testing with clinical trials on bioactive dental restorative composites/adhesives

(3) bioactive restorative materials

The exclusion criteria for the review were;

(1) literature not published in peer-reviewed journals

(2) the grey literature, that is information not reported in the scientific journals

(3) all papers in a foreign language (not in the English language), where full text was not available.

(4) where these bioceramics were incorporated 
in resin-modified glass ionomers and in glass ionomer cements.

\section{Study quality assessment}

The title and abstracts of all articles identified by the electronic search were read and assessed by two authors (ASK, MRS). The full-text article of all studies based on inclusion criteria was retrieved. As there are no defined guidelines for assessing the quality or risk of bias for in vivo and in vitro studies ${ }^{13,14)}$, therefore, the methodological quality of all selected full-text articles was assessed using the modified guidelines ${ }^{15}$. After application of the search strategy, two examiners (ASK and MK) reviewed and performed the selection by consensus with the objective of complementing the database searches. References in papers were checked and cross-matched with those from the original search. Where additional references were found to meet the inclusion criteria, then these were included in the review. After identifying the eligible studies in the above databases, these studies were imported into Endnote X7 software (Thompson Reuters, Philadelphia, PA, USA) to remove duplicates. Meta-analysis was considered if sufficient clinical studies existed.

\section{RESULTS}

\section{Study selection}

The original search strategy based on keywords mentioned in Table 1 resulted in 3,125 articles. However, the total number of papers, which met the inclusion criteria for the review, was 123 , whereby $53.65 \%$ and $46.34 \%$ of the papers were based on adhesives and composites, respectively. The flow chart of obtained results of the literature search is given in Fig. 1. Nonautomated manual searches were also conducted on the references within the selected articles. Among these studies, only two human trials ${ }^{16,17}$ and three in vivo studies $^{18-20)}$ on rat models were conducted, the rest were

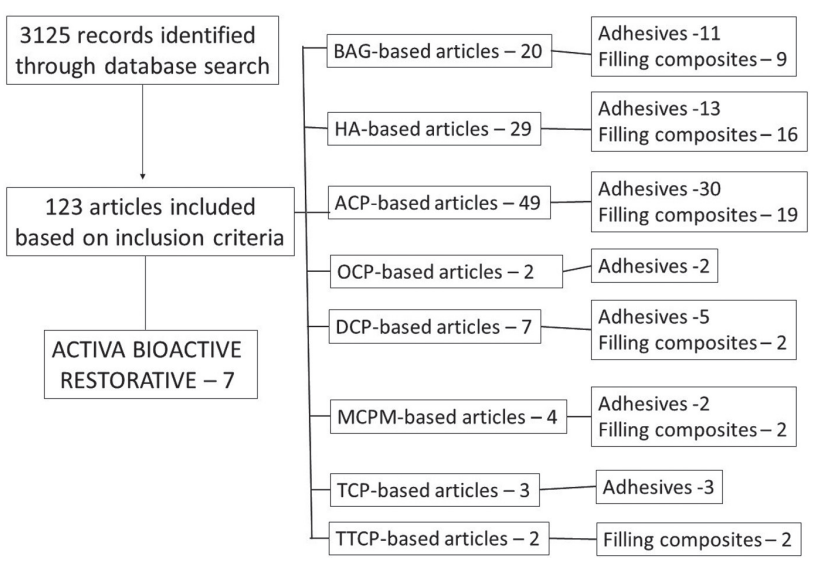

Fig. 1 Flow chart of literature search showing number of articles based on bioceramics incorporated dental resins. all analyzed in vitro conditions. Due to a lack of clinical studies, a meta-analysis was not considered.

\section{Results based on individual bioceramics-based restorative material}

The search data showed that articles published related to ACP, HA, BAG, DCP, MCPM, TCP, OCP and TTCP based dental resin-based restorative materials were 49 (39.83\%), 29 (23.5\%), 20 (16.2\%), 7 (5.69\%), 4 (3.25\%), $3(2.43 \%), 2(1.62 \%)$, and $2(1.65 \%)$, respectively. Moreover, the review showed 7 (5.69\%) published articles related to ACTIVA BioACTIVE-RESTORATIVE (Pulpdent, Watertown, MA, USA).

\section{ACP}

The search showed that a total of 49 studies $^{8,10,12,16-19,21-62)}$ had been conducted related to ACP-based resin restorative materials. Among these nano-amorphous calcium phosphate (NACP) had been used in 15 studies $^{19,21-31,57,58,62)}$, and the rest were based on microACP. Moreover, zirconia ${ }^{8,32-40)}$ and silica ${ }^{8,39,41)}$ had been hybridized with ACP to improve the mechanical and biological properties Nano-silver particles ${ }^{27,57)}$ and HA powder ${ }^{42}$ were also mixed with ACP to analyze the antibacterial and mechanical properties, respectively. In vivo studies were found related to human ${ }^{16,17)}$ and rat models ${ }^{18,19)}$. The laboratory and in vitro studies have been investigated in detail and are tabulated in Table 2.

\section{HA}

A total 30 studies $^{20,63-91)}$ was found to be based on the incorporation of $\mathrm{HA}$ in dental resin matrices, where microparticles ${ }^{20,63-72)}$, nano-particles/rods/fibers ${ }^{71,77-87,89,90)}$ and whiskers/fibrous ${ }^{73-80)}$ HA have been mainly used. A study showed the doping of silver in HA and investigated the in vitro bond strength ${ }^{88)}$. Only one other study exhibited an in vivo (rat model) biocompatibility analysis ${ }^{20)}$. The information about mechanical, physical and in vitro biological studies is given in Table 2 .

\section{BAG}

Among bioceramics, BAG is a relatively new material which has been incorporated into dental resin composites and adhesives. A total 20 studies $^{92-111)}$ was found as per the inclusion criteria, whereby seven studies ${ }^{92,94-96,98,106,108)}$ were based on fluoride-based bioactive glass (F-BAG). Few studies showed doping of zinc ${ }^{101,102,107)}$, silver ${ }^{110)}$, and niobiophosphate ${ }^{109)}$ in BAG powders. Experimental dental adhesives were also prepared by adding mineral trioxide aggregate (MTA) in BAG powder ${ }^{103,104)}$. The mechanical, physical, structural and in vitro biological properties have been investigated in detail and it is summarized in Table 2. Limited studies were found where MCPM/DCP ${ }^{9,112-118)}$ and $\mathrm{TCP}^{57,116,117,119)}$ had also been incorporated in dental resin matrices, including the investigation of their mechanical properties, ion release and water absorption.

\section{ACTIVA BioACTIVE-RESTORATIVE \\ ACTIVA BioACTIVE-RESTORATIVE (Pulpdent), has}


Table 2 Laboratory/in vitro studies conducted on bioceramics-based dental restorative materials

\begin{tabular}{|c|c|c|}
\hline $\begin{array}{l}\text { Bioceramics-based } \\
\text { restorative materials }\end{array}$ & Laboratory/in vitro studies & References \\
\hline \multirow{3}{*}{$\begin{array}{l}\text { Amorphous calcium } \\
\text { phosphate (ACP) }\end{array}$} & $\begin{array}{l}\text { Mechanical properties: } \\
\text { Flexural properties } \\
\text { Bond strength } \\
\text { Modulus of elasticity } \\
\text { Fracture toughness } \\
\text { Hardness } \\
\text { Diametral tensile/Compressive strength }\end{array}$ & $\begin{array}{l}12,21,26,27,29-31,36,38,40-50,57,58,62) \\
8,12,22,24,25,51-56,60,61) \\
43,44) \\
21,23) \\
17,39) \\
42)\end{array}$ \\
\hline & $\begin{array}{l}\text { Physical properties: } \\
\text { Ions (calcium and phosphorous) release } \\
\text { Water sorption } \\
\text { Polymerization shrinkage } \\
\text { Remineralization potential } \\
\text { Degree of conversion } \\
\text { Mineral changes } \\
\text { Acid neutralization }\end{array}$ & $\begin{array}{l}8,22,24,29-31,34-36,39,43,44,47,49,51,62) \\
35,41,47,49) \\
39,51) \\
10,24,28,34,50,52) \\
37,39,42) \\
59) \\
29-31)\end{array}$ \\
\hline & $\begin{array}{l}\text { In vitro biological: } \\
\text { Antibacterial study } \\
\text { Effect on dental plaque model } \\
\text { Cytotoxicity }\end{array}$ & $\begin{array}{l}21,24,27,29-31,45,46,57) \\
23-26,58) \\
51)\end{array}$ \\
\hline \multirow{3}{*}{ Hydroxyapatite (HA) } & $\begin{array}{l}\text { Mechanical properties: } \\
\text { Flexural strength } \\
\text { Modulus (flexural/Young's) } \\
\text { Compressive strength } \\
\text { Diametral tensile strength, hardness } \\
\text { Bond strength/tooth adhesion } \\
\text { Fracture toughness } \\
\text { Flexural fatigue }\end{array}$ & $\begin{array}{l}64,69-72,74,75,77-82,85-87,89) \\
64,69-72,75,77) \\
20,64,74,75,81,84) \\
20,71,72,75,78,82,84-87,89,90) \\
20,67,68,82,83,85,88) \\
77,81) \\
81)\end{array}$ \\
\hline & $\begin{array}{l}\text { Physical properties: } \\
\text { Degree of conversion } \\
\text { Water sorption } \\
\text { Polymerization reaction kinetics } \\
\text { Ion release } \\
\text { pH measurement } \\
\text { Depth of cure } \\
\text { Bioactivity }\end{array}$ & $\begin{array}{l}64-66,73,82) \\
69,70,73,76,79,90) \\
63,65,66) \\
67,68) \\
60) \\
85) \\
68)\end{array}$ \\
\hline & $\begin{array}{l}\text { In vitro biological: } \\
\text { Cytotoxicity } \\
\text { Dentin formation/pulp capping }\end{array}$ & $\begin{array}{l}89,91) \\
67,68)\end{array}$ \\
\hline \multirow{4}{*}{ Bioactive glass (BAG) } & $\begin{array}{l}\text { Mechanical properties: } \\
\text { Micro-tensile bond strength } \\
\text { Micro-hardness } \\
\text { Shear bond strength/flexural strength/ } \\
\text { fracture toughness/fatigue crack growth }\end{array}$ & $\begin{array}{l}103,104,107,109,110) \\
94-96,99,100,103,104,106) \\
99,105)\end{array}$ \\
\hline & $\begin{array}{l}\text { Physical properties: } \\
\text { Degree of conversion } \\
\text { Ion release } \\
\text { Acid neutralization } \\
\text { Water sorption } \\
\text { In vitro bioactivity } \\
\text { Viscosity } \\
\text { Optical } \\
\text { Dispersion analysis } \\
\text { Solubility }\end{array}$ & $\begin{array}{l}93,109) \\
99,106,108,111) \\
99,100,106,108) \\
93,100,103,104) \\
110) \\
93,100) \\
94-96) \\
93) \\
103,104)\end{array}$ \\
\hline & Structural & 107) \\
\hline & $\begin{array}{l}\text { In vitro biological: } \\
\text { Cytotoxicity } \\
\text { Dentin remineralization } \\
\text { Antibacterial testing } \\
\text { Bacterial film formation }\end{array}$ & $\begin{array}{l}\text { 98) } \\
92,101-103,106) \\
97,110) \\
94-96)\end{array}$ \\
\hline
\end{tabular}


been used as a base or liner, as well as in bulk-fill, post, and core build-up procedures. It consists of a proprietary bioactive ionic resin, a rubberized resin, and is also photopolymerizable ${ }^{120)}$. A total of nine studies were found to be relevant to this material, however, seven studies ${ }^{121-127)}$ were selected, as two studies ${ }^{128,129)}$ were excluded as per the selection criteria. The flexural strength ${ }^{122)}$, flexural fatigue ${ }^{122)}$, wear ${ }^{123)}$, shear bond strength ${ }^{124)}$, cell viability ${ }^{125)}$, biomineralization ${ }^{125)}$, and bacterial leakage $^{121)}$ had been investigated in these studies.

\section{DISCUSSION}

The purpose of the current systematic review was to organize dental resin-based bioceramic restorative materials into its component parts. The review demonstrated that mainly structural, physical, mechanical, and biological effects of bioceramics based restorative materials have been investigated. Although bioactive dental resin-based materials have been studied since 1988 , in vitro studies were mainly identified. There are inadequate clinical studies evaluating the relative benefits of these bioactive dental restorative materials.

Restorative materials based on bioceramics (ACP, HA, DCPD, TCP, and BAG) have been used in operative dentistry and periodontology and less commonly in prosthodontics and endodontics ${ }^{130,131)}$. These materials are biocompatible, harmless, non-irritating, noninflammatory, and non-toxic, and have the benefits of minimal bioresorption ${ }^{132,133)}$. It is important to know, why most studies are based on ACP, HA and BAG and very few on MCPM, TCP, and TTCP. There are certain factors such as solubility, ion ratio, mode of synthesis, mechanical properties and morphology which determine the properties of these restorative materials.

It is suggested that if the ratio of calcium and phosphorous precursors is less than 1 , then the solubility of the resulting material will be high, whereas with an increase in the ratio (i.e. close to 1.67 ), this parameter may decrease substantially ${ }^{134)}$. The $\mathrm{Ca} / \mathrm{P}$ ratio of $\mathrm{ACP}$, $\mathrm{DCPD}$ is 1.0 and for MCPM is 0.5 . The apatite structure can be preserved with a $\mathrm{Ca} / \mathrm{P}$ ratio as low as 1.5 , therefore, HA with a lower than normal ratio (1.67) may be characterized as calcium deficient or non-stoichiometric. When the molar ratio is lower than 1.67, HA partially decomposes to $\beta$-TCP at a higher temperature ${ }^{135)}$.

Similarly, the solubility of BAG can be controlled by changing its composition, for example, by partially or fully replacing the silica with borate ${ }^{136)}$. Another possibility is to exploit the compositional flexibility of glass so that it can also serve as a source of many minor elements such as $\mathrm{Zn}, \mathrm{Cu}, \mathrm{F}, \mathrm{Mn}, \mathrm{Sr}$ and B. As the glass degrades in vivo, these elements are released at an acceptable rate and are known to favor biological tissue growth ${ }^{137)}$.

The solubility of these bioceramics (CP family and BAG) is mainly based on their mode of synthesis with varying reaction time, temperature, structure and $\mathrm{pH}$. An increase in reaction time, temperature, crystalline structure and a decrease in $\mathrm{pH}$ can reduce the solubility ${ }^{138,139)}$. The solubility determines the release of calcium, phosphate, and silica ions from dental resins, and consequently, the remineralization process.

The other factor that determines the resultant properties of restorative materials is the morphology of the bioceramic particles. The morphology depends upon the process of synthesis process and heat treatment. The heating temperature affects the particle shape and agglomeration, whereby at low temperatures the crystals are in a needle shape, whereas increasing the reaction temperature may change the crystal from a needle shape to a more circumscribed shape, or more close to a spherical shape ${ }^{140,141)}$.

Nano-particles, with a high surface area, has been shown to enhance the mechanical properties but agglomeration can decrease the physical and mechanical properties and these issues have been observed in various studies ${ }^{75,89)}$. As a uniform distribution is difficult to accomplish, manual spatulation was therefore mostly utilized in these experimental studies, so as to mix the fillers into resin matrices ${ }^{24,30,58,90)}$. However, it has been reported that the fillers should be stirred overnight ${ }^{75}$ ) to avoid any aggregation and to achieve a uniform distribution. It was also suggested to use solvents i.e. acetone and ethanol for mixing ${ }^{90)}$, where ethanol is not reactive enough to interfere the reaction, rather residual ethanol can increase the polymerization reaction ${ }^{142)}$.

\section{ACP based dental resins}

Currently, almost $39.83 \%$ of studies are based on ACP based materials. However, a concern is observed about their inherent poor mechanical properties, therefore, it has been hybridized with other ceramics (zirconia, silica), and metals (barium, strontium, silver) ${ }^{143)}$. Its flexural strength is about half that of the unfilled resins which make it inefficient for use as a bulk restoration under masticatory load. ACP has been used as a filler in dental adhesives and composites due to its bioactivity, biocompatibility, osteoconduction and better cell adhesion with both hard tissues ${ }^{144)}$. It can increase alkaline phosphatase activities of mesoblasts, enhance cell proliferation and promote cell adhesion. Many enzymes, proteins and ions affect the biomineralization of ACP such as dentin matrix protein ${ }^{145)}$. The ACP based composites can potentially be used as restorations in small carious lesions, sealing pits and fissures in teeth where plaque can accumulate and may lead to secondary caries ${ }^{146)}$. The composites containing ACP fillers have shown a $71 \%$ recovery of the lost mineral content of decalcified teeth ${ }^{8)}$. This material can be added in orthodontic adhesives and may help to avert demineralization of tooth enamel ${ }^{18,147)}$, minimize white spot lesion formation and prevent accumulation of bacterial plaque around fixed orthodontic brackets and bands ${ }^{59)}$. However, commercialization of the product would be difficult because approval from the Food and Drug Administration (FDA) requires the classification of these agents as a drug. The FDA has approved a therapeutic paste i.e. Recaldent ${ }^{\mathrm{TM}}$ (Recaldent Pty, Melbourne, Australia), in which the ACP has been used in 
a paste that contains casein phosphopeptide-amorphous calcium phosphate (CPP-ACP $)^{148)}$. Another ACPcontaining light-cured orthodontic adhesive product has been marketed as Aegis ${ }^{\circledR}$-Ortho (The Bosworth, Skokie, IL, USA) ${ }^{59)}$. An in vitro study ${ }^{60)}$ has showed that Aegis ${ }^{\circledR}$ Ortho has an adequate bond strength for orthodontic purposes. An in vivo study ${ }^{16)}$ involving the survival rate of orthodontic brackets over a 12-month period using Aegis ${ }^{\circledR}$-Ortho as compared to a conventional adhesive, showed that the bond failure rates of the conventional adhesive and Aegis $^{\circledR}$-Ortho adhesive were 2.67 and $3.8 \%$, respectively, and that there was no significant difference between these two systems. Thus, it can be concluded that ACP has the ability to effectively remineralize enamel caries lesions in vitro ${ }^{61)}$.

Many studies have been carried out to improve the properties of fabricated $\mathrm{NACP}^{149)}$. $\mathrm{Xu}^{150)}$ patented and used NACP, wherein the particles size was about 10$500 \mathrm{~nm}, 5-90 \mathrm{wt} \%$ was used in the composite whereby comparable mechanical and antibacterial properties to commercial composites was decreased. Melo et al. ${ }^{24)}$ incorporated NACP (0, 10, 20, 30, and 40 wt\%) and nano-silver 2-ethylhexanoate particles in Scotchbond ${ }^{\mathrm{TM}}$ Multipurpose (3M ESPE, St. Paul, MN, USA) and it was found that NACP and nano-silver based bonding agent exhibited a strong dentin bond strength and also showed a potent antibacterial activity. NACP itself had shown little antibacterial activity, however with the addition of $0.1 \%$ nano-silver, the antibacterial properties had improved, and the dentin bond strength remained stable with an increase in the concentration of NACP. Figure 2 shows the dentin-adhesive interface and it was observed that adhesives filled the dentinal tubules and the resin tags were formed. The hybrid layer was indicated to be between the adhesive and the underlying mineralized dentin. Numerous NACP nanoparticles in the adhesive layer were observed in the hybrid zone, as well as inside the dentinal tubules.

Zhang et $a l .{ }^{62)}$ used NACP and developed the first generation of rechargeable $\mathrm{CaP}$ composites, showing a substantial recharge together with the sustained longterm release of $\mathrm{Ca}^{2+}$ and $\mathrm{P}^{3+}$ ions for remineralization and caries-inhibition. In addition to low mechanical properties and its inability to resist cracking under masticatory stress, the inherent issue in ACP composites is an aggregation of ACP particles. This problem has been considered to be one of the main reasons for relatively poor interfacial ACP-resin interactions which also subsequently lead to low mechanical strength when compared with silanized glass-reinforced composites ${ }^{43)}$. Therefore, strategies have been developed to address this issue and to enhance the ACP filler-polymer matrix interfacial properties by better controlling the particle size distribution and surface properties, this being done by the fine-tuning of the resin ${ }^{151)}$.

\section{HA-based dental resins}

$\mathrm{HA}$ is the most stable form of CP compounds in vivo ${ }^{152)}$. Okazaki and $\mathrm{Ohmae}^{20)}$ were the first to use crystallized $\mathrm{HA}$ in dental composites and claimed that when the
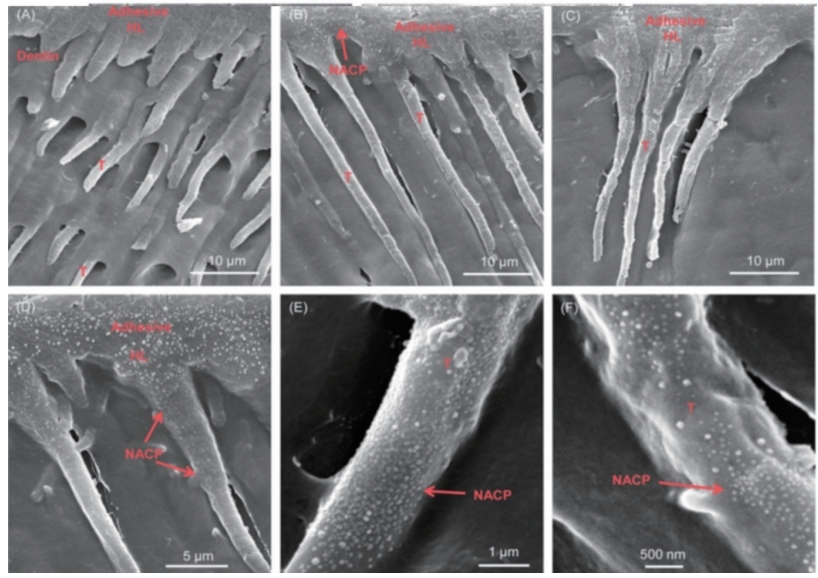

Fig. 2 SEM micrographs of dentin-adhesive interfaces. (A) Scotchbond Multipurpose, (B) Primer and adhesive+nano-silver $+20 \%$ NACP, (C) Primer and adhesive+nano-silver+40\% NACP, (D) P+NAg, $\mathrm{A}+\mathrm{NAg}+20 \% \mathrm{NACP}$ at a higher magnification, and $(\mathrm{E}, \mathrm{F})$ at even higher magnifications. Arrows indicate NACP in the dentinal tubules (Courtesy to Melo et al. $)^{24)}$.

$\mathrm{Ap} / \mathrm{R}$ ratio 1 then it is almost equal to that of teeth and the composites adhered well to enamel without a bonding agent. Various studies ${ }^{70,90)}$ were conducted to compare silanized and non-silanized HA in resin matrix and an enhancing effect was found on the mechanical and physical properties of the composite with silanized $\mathrm{HA}^{90)}$. However, it has been previously reported that by adding nano-HA as a filler, the material then becomes unsuitable for clinical performance and is hydrolytically unstable as compared to composites with microscopic particles $^{86,87)}$. The hydrophilicity of $\mathrm{HA}$ is due to the presence of the $-\mathrm{OH}$ group in its hexagonal structure that can easily attract surface moisture ${ }^{153)}$, however it can be addressed with surface grafting during in situ synthesis ${ }^{154)}$.

This review study reflects a trend towards the use of nano-filler particles/fibers in dental resins, which could be due to their inherent characteristics of a high surface area, offering good mechanical interlocking with the polymer matrix. However, it has been reported that flexural strength, fracture toughness and compressive strength values decreased with an increase in the concentration of nano-HA and nano-HA whiskers in resin matrices ${ }^{74,77)}$. It has been suggested in these studies that a specific decrease in the percentage of filler content might be related to the agglomeration of fillers ${ }^{73)}$. HA has relatively better mechanical properties than ACP, however still not at a satisfactory level. The fracture toughness of dense and porous HA has been

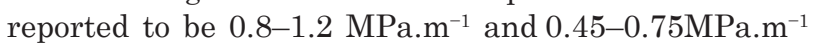
respectively ${ }^{155)}$. The reported bending and compressive strength of dense and porous HA were found to be 38$250 \mathrm{MPa}, 120-150 \mathrm{MPa}$, and 2-11 MPa, 2-100 MPa, respectively ${ }^{156-160)}$. Due to its low mechanical properties, 

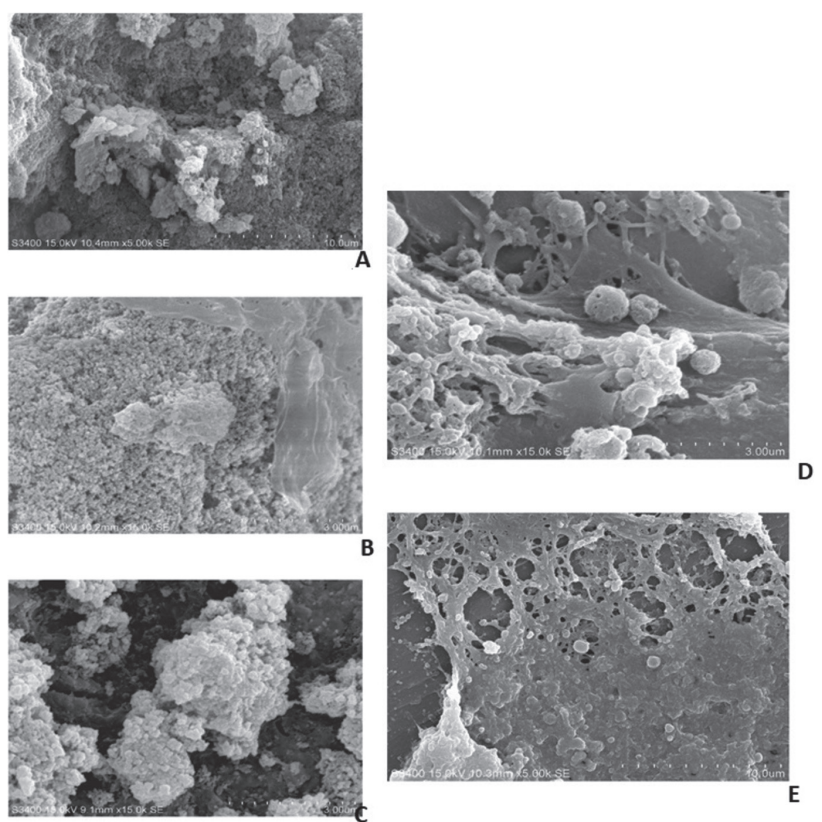

Fig. 3 SEM images after $36 \mathrm{~h}$ of cell culturing on composite resins, (A) 100\% resin matrix, (B) Resin matrix $+\mathrm{HA} 30 \%$, (C) Resin matrix $+\mathrm{HA} 50 \%$, (D) Resin matrix + HA15\%/silica $15 \%$, and (E) Resin mastrix + HA25\%/silica25\% (Courtesy to Chadda et $a l.)^{91)}$.

this material has limitations in load-bearing clinical applications. The main reason for its low mechanical properties is its porosity, which makes it easier for micro and macro cracks ${ }^{161)}$. Therefore, in some studies, instead of using particulates; fibers and whiskers have been used which have yielded relatively better mechanical results. The same trend has been observed when HA nano-fibers were added with micro-size silica particles. The dental composite with $3 \mathrm{wt} \%$ nano-HA fibers and $57 \mathrm{wt} \%$ silica micro-particles had a $29.2 \%$ higher biaxial flexural strength in comparison with the control specimen without nano-HA. It was thus suggested that the double-edged effects i.e. the reinforcing and weakening effects may be due to well dispersion and agglomeration, respectively, and can be produced with the impregnation of nano-HA fibers into dental resin ${ }^{80)}$.

Recently, in a similar study ${ }^{89)}$, nano-whiskers were incorporated (0-100 vol\%) into dental resin and the mechanical properties thereof were compared to commercial composites. It was found that HA whiskers with a $20 \mathrm{vol} \%$ showed comparable results to commercial composites. Khalid et al. ${ }^{162)}$ added silanized nano-HA in dental resins in two different ratios and compared it to micro-hybrid and flowable composites. It was revealed that experimental composites had a better degree of conversion and minimal leaching of unreacted monomers when compared to commercial composites. The in vitro cytotoxicity of HA-based dental composites was evaluated and it was found that all experimental composites with
$\mathrm{HA}$ and $\mathrm{HA} /$ silica were non-toxic, signifying that these composites exhibited favorable biological behavior which may also support cell proliferation ${ }^{91}$. Figure 3 shows the attachment of human bone marrow (hBM) mesenchymal stem cells (MSC) to all composite resins based on HA and $\mathrm{HA} /$ silica. The features of cell attachment were observed to be different on the surfaces of these composites based on their material properties. The most commonly observed morphologies were unipolar, bipolar, rounded, and flattened (amoeboid) shapes. However, they all supported hMSC attachment, whereby prominent cell spreading was seen in composites with $\mathrm{HA} /$ silica.

\section{TCP/MCPM based dental resins}

It has been suggested that pure HA has a too low dissolution rate, therefore, improvisations such as the usage of biphasic apatites (HA/TCP) can provide optimum resorbability and dissolution rates. Furthermore, pure TCP is highly soluble and has high dissolution rate which forms HA. The dissolution order of the CP family is: TTCP $>\alpha-\mathrm{TCP}>\mathrm{DCPD}>\mathrm{DCPA}>\mathrm{OCP}>\beta$ $\mathrm{TCP}>\mathrm{HA}^{144)}$. $\quad \beta$-TCP has been used primarily in synthesizing biphasic or monophasic bioceramics and $\alpha$-TCP is part of many bone cements. $\beta$-TCP has been used more extensively in clinical applications of dentistry, maxillofacial surgery, tissue engineering and orthopedics than $\alpha$-TCP ${ }^{163-165)}$. In dental composite, TCP as a filler has been reported to increase water absorption due to the loss of minerals when it comes into contact with water, which further causes weakening of the mechanical strength of filling. The mechanical properties (flexural strength and modulus) have been shown to decrease with the addition of $\mathrm{CP}$; however, the lowest obtained value was $101 \mathrm{MPa}$, which showed comparative strength to commercial composites. It has been reported that these composites have the potential to solve issues of microleakage and recurrent caries as well as to promote the remineralization of demineralized dentin. Tri strontium phosphate, polylysine, and MCPM have been incorporated into dental resins and the results showed that this promoted hygroscopic expansion, apatite formation, and early polylysine release ${ }^{118)}$. A newly developed apatite layer was formed after immersing these composites in simulated body fluid (SBF) for 4 weeks and it was further observed that after 4 weeks the layer thickness was approximately 20 $\mu \mathrm{m}$ as shown in Fig. 4 .

\section{$B A G$ based dental resins}

In 1969, Larry Hench and his co-workers laid the foundation of bioactive ceramics by developing Hench's 45S5 Bioglass ${ }^{\circledR}$, which was found to be successfully bonded in a chemical manner to the hard tissues. There are different types of biocompatible BAG, for example, conventional Hench's Bioglass ${ }^{\circledR}$, as well as phosphatebased bioglass and borate-based bioglass which have been later introduced ${ }^{166,167)}$. Sauro et al. ${ }^{107)}$ investigated the therapeutic effects of Bioglass 45S5 and zincpolycarboxylated BAG-based dental composites on the bonded-dentin interface. The dimethacrylate-based 

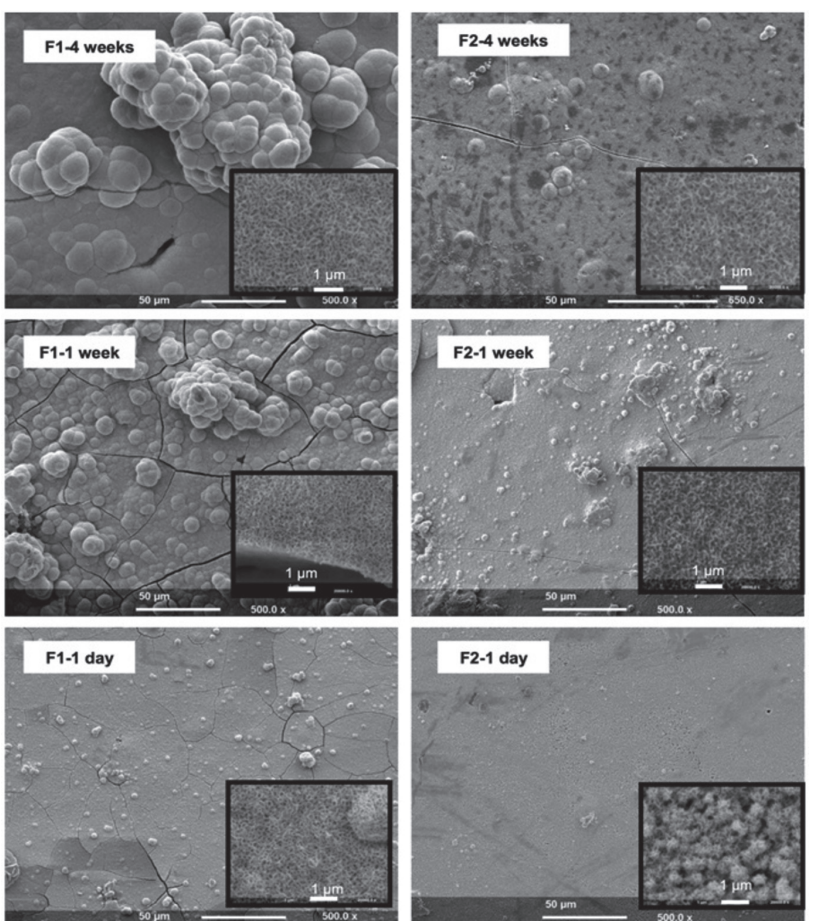

Fig. 4 SEM images of resin-based composites with MCPM/Tri-strontium with (F1) and without (F2) polylysine showing apatite layer after immersing in SBF for periodic time interval (Courtesy to Panpisut et $a l.)^{118)}$.

resin matrices were used, and the concentration of these particles was $33 \mathrm{wt} \%$. The experimental composite showed an increase in nano-mechanical properties, while simultaneously reducing the micro-permeability along the dentin-bonded interface, this occurring by means of the therapeutic remineralization of imperfect mineral-depleted areas as shown in Fig. 5. Furthermore, the surface of the specimen exhibited several 'funnelled' dentinal tubules with no exposed collagen fibrils and it was mainly protected by residual resin and mineral crystals which were embedded within a resin/collagen network. Both BAG and F-BAG resins induced the precipitation of mineral contents inside the dentinal tubules and onto the surface. Also, the F-BAG resins showed a higher modulus of elasticity (13\%) and an increase in stiffness of demineralized dentin when compared to BAG-based samples and control samples. This might be due to the release of fluoride and phosphate ions, which can accelerate the remineralization process. Recently, F-BAG and BAG have been added in dimethacrylate based resins and it has been found that F-BAG based composite shows more bioactivity than conventional BAG, as well as accelerated dentin remineralization, F-BAG furthermore showed a higher ability to reduce the solubilization of C-terminal crosslinked telopeptides (ICTP) and C-terminal telopeptides ${ }^{92)}$. Khvostenko et al. ${ }^{96)}$ synthesized BAG (15 wt\%) and incorporated it into resin matrices along with strontium
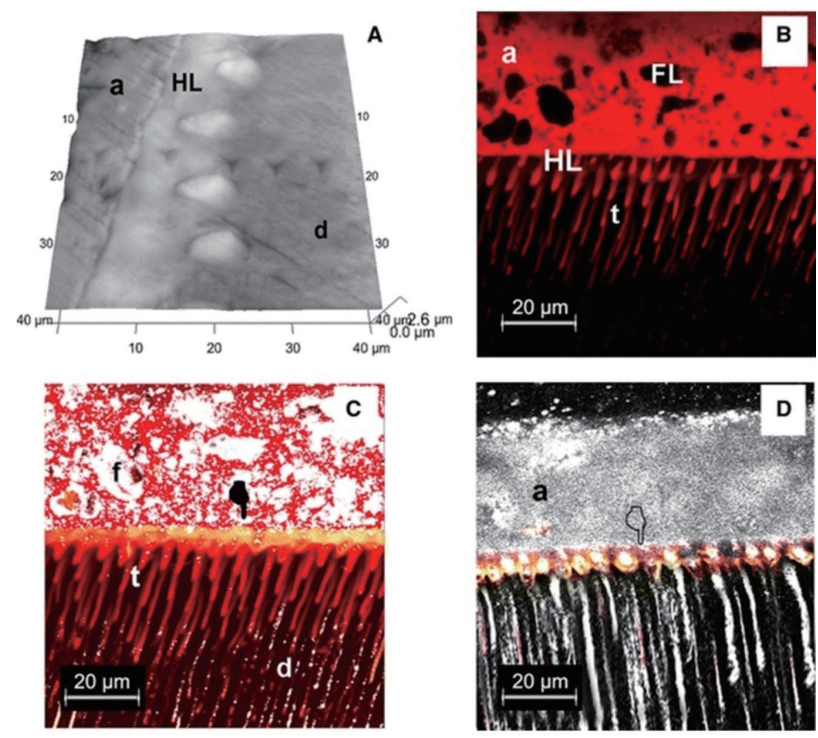

Fig. 5 (A) AFM image showing the resin-dentin interface created with resin based on BAG/Zn after 3 month storage in SBF showing a clear indentation mark on the hybrid layer (HL), (B) This confocal scanning microscope image showing a clear HL with long resin tags penetrating the dentinal tubules ( $\mathrm{t}$ ) and a substantial presence of BAG-Zn filler (FL) within the adhesive layer, (C) Reflection/fluorescence lacune mode showing a resin-dentin interface characterized by a porous HL completely infiltrated by the LY dye (pointer) after $24 \mathrm{~h}$ of SBF solution storage, and (D) The confocal scanning microscope single projection image captured from resindentin interfaces after prolonged SBF storage (3 $\mathrm{m})$ showing a strong reflection signal both in HL and dentinal; a limited micropermeability at the bottom of the HL is also evident (pointer) (Courtesy to Sauro et al. $)^{107)}$.

glass and their in vitro study showed a significant antimicrobial effect by reducing the extent of bacterial biofilm penetration into pre-existing marginal gaps.

In the last five years, the trend has shifted towards BAG based dental restorative materials as compared to $\mathrm{HA}$ and ACP. One reason could be due to the inherent property of remineralization as well as the inhibition of bacterial decay. The antimicrobial effect of BAG is attributed to the release of ions such as those from calcium and phosphate that have a toxic effect on oral bacteria, which also tend to neutralize the local acidic environment ${ }^{96)}$.

\section{ACTIVA BioACTIVE-RESTORATIVE}

A relatively new resin modified restorative material product ACTIVA BioACTIVE (Pulpdent) was marketed in 2013 and has shown continuous passive diffusion of calcium, phosphate and fluoride ions through the restorative material. According to manufacturers, ACTIVA RESTORATIVE is the first commercial bioactive dental material with ionic resins ${ }^{126)}$. ACTIVA 
is a dual cure material with self-adhesive properties and comes in the form of bulk-fil flowable (http://www. pulpdent.com/activa-bioactive-bulk-fill).

It consists of diurethane modified by the insertion of hydrogenated polybutadiene and other methacrylate monomers, polyacrylic acid, silica, and sodium fluoride $^{123)}$, Another study has confirmed the presence of BAG (55.4 wt\%) in this material ${ }^{129}$, however, the actual composition is not known due to commercial reasons. ACTIVA BioACTIVE-RESTORATIVE is a bioactive composite that can chemically bond to teeth, restricts bacterial ingression, releases fluoride, and therefore delivers all the advantages of glass ionomers in a strong, resilient, resin matrix ${ }^{124}$. This composition allows for the release of calcium, phosphate, and fluoride; it enhances wear-resistance and fracture-resistance; protects against microleakage; and has antibacterial properties ${ }^{120}$. ACTIVA BioACTIVE-RESTORATIVE has also shown less bacterial leakage (80\% less) compared to RMGIC and zinc phosphate cement ${ }^{1211}$.

Bansal et al. ${ }^{123)}$ investigated the wear pattern of Activa Bioactive and it was observed that abrasive wear occured due to shear forces applied by the antagonist subsequently causing a fracture in the microscopic surface of materials. The elastic modulus of this bioactive composite was higher than that of RMGIC and conventional GIC i.e. $4.45 \mathrm{GP}, 2.89 \mathrm{GPa}$, and 2.57 $\mathrm{GPa}$, respectively. Due to the high modulus of Activa Bioactive, it withstood the repeated cyclic stress and its superior flexural fatigue attributed to the resilience of its modified resin matrix. An in vitro study ${ }^{125)}$ with human dental pulp stem cells (hDPSC) showed that the elutes of Activa Bioactive were more cytotoxic compared to calcium hydroxide-incorporated (Dycal Dentsply, York, PA, USA) and MTA-like incorporated (Theracal, Bisco, Schaumburg, IL, USA) pulp capping materials. Furthermore, it was claimed that Activa Bioactive exhibited the potential to stimulate biomineralization at the same level as other pulp capping materials and that it released the same amount of $\mathrm{Ca}$ and $\mathrm{OH}$ ions.

The comparison of the shear bond strength of Activa Bioactive with Biodentine (Septodont, Orange, CA, USA), Ever X posterior (GC, Tokyo, Japan) and SDR surefil (Dentsply) showed that Activa had a higher bond strength as compared to Biodentine but lesser than SDR and Ever X. However, it was claimed that the physical properties of Activa were comparable to that of RBC. The other advantage is easy handling as the material is left undisturbed for about $20 \mathrm{~s}$ after injection, the physical handling thereof thus allowing the polyacid component to etch the tooth ${ }^{124)}$. Another study ${ }^{122)}$ compared the flexural strength and flexural fatigue of ACTIVA BioACTIVE-RESTORATIVE to flowable composite (Tetric Evo Flow), resin modified glass ionomer cement (Geristore) and conventional GIC (Fuji IX), whereby it was found that the flowable composite demonstrated aa higher flexural strength $(115.2 \mathrm{MPa})$ and flexural fatigue (68.4 MP) as compared to ACTIVA BioACTIVERESTORATIVE (105.4 and $63.7 \mathrm{MPa}$, respectively). However, the flexural strength of flowable composite and ACTIVA BioACTIVE-RESTORATIVE were above the minimum requirement of ISO 4049 for occlusal restorations i.e. $80 \mathrm{MPa}$. Thus, these materials are suitable in stress-bearing areas. However, the flexural strength values of RMGIC and conventional GIC did not meet the minimum requirement of ISO specification. This new class of bioactive materials with remineralizing properties offers promise to reverse tooth decay, regain lost minerals, and inhibit recurrent caries ${ }^{120)}$.

Recently, calcium silicate-based materials have gained acceptance for dental application due to their resemblance to MTA. One of the products which have been widely accepted is 'Biodentin ${ }^{\mathrm{TM}}$ ', the dentin replacement material, and it is commercially available since 2009 by Septodont (http://www.septodontusa.com/ products/biodentin). The main components of Biodentin are tricalcium silicate, dicalcium silicate, calcium carbonate, and zirconium oxide. Calcium chloride and hydrosoluble polymer are the liquid components ${ }^{168)}$.

\section{CONCLUSION}

It is concluded from this review that the use of bioceramics in dentistry has gained interest in the last decade and it is an example of the evolution in dental resin-based restorative materials. However, it was found to be mostly added to dental adhesives as compared to direct restorative filling composites. Among these, ACP was used the most frequently followed by HA, BAG, DCP, and MCPM. Few studies were however based on TCP and TTCP. The trend of using nano-particles/fibers was also discussed in this review and $25 \%$ of studies showed the usage of nano-materials (NACP and nano-HA) in dental resin restorative materials. Although the effects of bioceramics have been investigated since 1988, only two human trials and three in vivo (rat models) studies have been conducted. In vitro studies were mainly focused on mechanical properties followed by physical, chemical and biological properties to evaluate the performance of these restorative materials. Recently, ACTIVA BioACTIVERESTORATIVE (Pulpdent) has been introduced as a bioactive RBC, but still this material needs further thorough investigation as only nine studies have been found to date. With the advent of bioceramics-based restorative materials, dental professionals will be able to produce sophisticated restorations, bonding elements, and effective interfacial adhesion. By understanding the chemical, physical and biological nature of these restorative materials, the clinician will be able to choose the appropriate materials as needed and produce a highquality product to satisfy the patient's dental needs.

\section{FUTURE DIRECTIONS}

It is well established that bioceramics (i.e. HA, ACPs and BAG) have excellent biological, exceptional biocompatible and bioactive properties due to similarity with human hard tissues. The restorative materials based on these bioceramics have shown their potential to be used in clinical dentistry. However, concern has been noticed in 
terms of their mechanical properties. Therefore, in future, more research is required to improve their physical and mechanical properties without decreasing the biological potential. A further need is to improvise their design and processing parameters to limit their brittleness, so it can be used in load bearing (masticatory load) area. Ionic substitution in bioceramics can improve the biological and mechanical properties; as an iono-covalent structural model of the CP family seems ready to accept both cationic and anionic substituents. These substitutions may induce modifications in the lattice parameters as well as in the crystallinity of the materials, both of which are responsible for influencing the solubility of these materials under physiological conditions. Surface modification during the in situ synthesis and doping with amine, bromine, and with metal ions can also lead to the improvement in the properties of fillers, and subsequently as well as dental restorative composites. A new challenge will be to increase the toughness and it is anticipated that co-precipitation with ceramics such as zirconia, titania, alumina can enhance the physical and mechanical properties of restorative composites. The reported studies on bioceramics-based restorative materials are mainly based on in vitro testing and little attention has been paid to their in vivo and clinical applications. Therefore, it will be required to evaluate the clinical application of these materials within the physiological limits of masticatory loads. This review has shown that bioceramics-based dental restorative composites have produced tremendous results, however, further research is required to fully investigate the potential performance of these composites in clinical applications.

\section{ACKNOWLEDGMENTS}

The authors would like to thank Dr. Maria Khan for her assistance in reviewing the final data and Dr. Steph Smith for helping in proof reading. Further report that no financial funding and support was received in the preparation of this manuscript.

\section{CONFLICT OF INTEREST}

The authors have no conflict of interest to disclose.

\section{REFERENCES}

1) Ferracane JL, Giannobile WV. Novel biomaterials and technologies for the dental, oral, and craniofacial structures. J Dent Res 2014; 93: 1185-1186.

2) Khan AS, Aamer S, Chaudhry AA, Wong FS, Rehman IU. Synthesis and characterizations of a fluoride-releasing dental restorative material. Mater Sci Eng C 2013; 33: 3458-3464.

3) Cheng L, Zhang K, Zhang N, Melo M, Weir M, Zhou X, Bai Y, Reynolds M, Xu H. Developing a new generation of antimicrobial and bioactive dental resins. J Dent Res 2017; 96: 855-863

4) Eliaz N, Metoki N. Calcium phosphate bioceramics: A review of their history, structure, properties, coating technologies and biomedical applications. Materials 2017; 10: 334.

5) Yoshihara K, Nagaoka N, Maruo Y, Sano H, Yoshida Y, Van
Meerbeek B. Bacterial adhesion not inhibited by ion-releasing bioactive glass filler. Dent Mater 2017; 33: 723-734.

6) Khan A, Hussain A, Sidra L, Sarfraz Z, Khalid H, Khan M, Manzoor F, Shahzadi L, Yar M, Rehman I. Fabrication and in vivo evaluation of hydroxyapatite/carbon nanotube electrospun fibers for biomedical/dental application. Mater Sci Eng C 2017; 80: 387-396.

7) Mir M, Anwar Siddiqi S, Hussain T, Anwar Chaudhry A, Ur Rehman I, Khan AS, Abbas G. Synthesis and characterization of calcium deficient apatite granules for drug eluting bone graft applications. Ceram Int 2014; 40: 10719-10725.

8) Skrtic D, AntonucciJ, Eanes E. Amorphous calcium phosphatebased bioactive polymeric composites for mineralised tissue regeneration. J Res Nat Inst Stand Technol 2003; 108: 167182.

9) Chiari MD, Rodrigues MC, Xavier TA, de Souza EM, AranaChavez VE, Braga RR. Mechanical properties and ion release from bioactive restorative composites containing glass fillers and calcium phosphate nano-structured particles. Dent Mater 2015; 31: 726-733.

10) Skrtic D, Hailer AW, Takagi S, Antonucci JM, Eanes ED. Quantitative assessment of the efficacy of amorphous calcium phosphate/methacrylate composites in remineralizing carieslike lesions artificially produced in bovine enamel. J Dent Res 1996; 75: 1679-1686.

11) Khan A, Ahmed Z, Edirisinghe M, Wong F, Rehman I. Preparation and characterization of a novel bioactive restorative composite based on covalently coupled polyurethane-nanohydroxyapatite fibres. Acta Biomater 2008; 4: 1275-1287.

12) Schumacher GE, Antonucci JM, O’Donnell JN, Skrtic D. The use of amorphous calcium phosphate composites as bioactive basing materials: their effect on the strength of the composite/adhesive/dentin bond. J Am Dent Assoc 2007; 138: 1476-1484.

13) Plint AC, Moher D, Morrison A, Schulz K, Altman DG, Hill C, Gaboury I. Does the CONSORT checklist improve the quality of reports of randomised controlled trials? A systematic review. Med J Aust 2006; 185: 263-267.

14) Krauth D, Woodruff TJ, Bero L. Instruments for assessing risk of bias and other methodological criteria of published animal studies: a systematic review. Environ Health Perspect 2013; 121: 985-992.

15) Ramamoorthi M, Bakkar M, Jordan J, Tran SD. Osteogenic potential of dental mesenchymal stem cells in preclinical studies: a systematic review using modified arrive and consort guidelines. Stem Cells Int 2015; 2015: 378368.

16) Hammad SM, El Banna MS, Elsaka SE. Twelve-month bracket failure rate with amorphous calcium phosphate bonding system. Eur J Orthod 2013; 35: 622-627.

17) Uysal T, Amasyali M, Ozcan S, Koyuturk AE, Akyol M, Sagdic D. In vivo effects of amorphous calcium phosphate-containing orthodontic composite on enamel demineralization around orthodontic brackets. Aust Dent J 2010; 55: 285-291.

18) Agarwal A, Swami V, Sable R. Comparative study of amorphous calcium phosphate-containing orthodontic composite and conventional orthodontic adhesive on enamel demineralization around orthodontic brackets - An in vivo study. Orthodon J Nep 2014; 3: 11-17.

19) Li F, Wang P, Weir MD, Fouad AF, Xu HHK. Evaluation of antibacterial and remineralizing nanocomposite and adhesive in rat tooth cavity model. Acta Biomater 2014; 10: 2804-2813.

20) Okazaki M, Ohmae H. Mechanical and biological properties of apatite composite resins. Biomaterials 1988; 9: 345-348.

21) Wu J, Weir MD, Melo MAS, Xu HHK. Development of novel self-healing and antibacterial dental composite containing calcium phosphate nanoparticles. J Dent 2015; 43: 317-326.

22) Zhang L, Weir MD, Hack G, Fouad AF, Xu HHK. Rechargeable 
dental adhesive with calcium phosphate nanoparticles for long-term ion release. J Dent 2015; 43: 1587-1595.

23) Wu J, Zhou H, Weir MD, Melo MAS, Levine ED, Xu HHK. Effect of dimethylaminohexadecyl methacrylate mass fraction on fracture toughness and antibacterial properties of CaP nanocomposite. J Dent 2015; 43: 1539-1546.

24) Melo MAS, Cheng L, Zhang K, Weir MD, Rodrigues LKA, $\mathrm{Xu}$ HHK. Novel dental adhesives containing nanoparticles of silver and amorphous calcium phosphate. Dent Mater 2013; 29: 199-210.

25) Melo MAS, Weir MD, Rodrigues LKA, Xu HHK. Novel calcium phosphate nanocomposite with caries-inhibition in a human in situ model. Dent Mater 2013; 29: 231-240.

26) Zhou C, Weir MD, Zhang K, Deng D, Cheng L, Xu HHK. Synthesis of new antibacterial quaternary ammonium monomer for incorporation into $\mathrm{CaP}$ nanocomposite. Dent Mater 2013; 29: 850-870.

27) Cheng L, Weir MD, Xu HHK, Antonucci JM, Lin NJ, LinGibson S, Xu SM, Zhou X. Effect of amorphous calcium phosphate and silver nanocomposites on dental plaque microcosm biofilms. J Biomed Mater Res Part B Appl Biomater 2012; 100: 1378-1386.

28) Weir MD, Chow LC, Xu HHK. Remineralization of demineralized enamel via calcium phosphate nanocomposite. J Dent Res 2012; 91: 979-984.

29) Moreau JL, Sun L, Chow LC, Xu HHK. Mechanical and acid neutralizing properties and bacteria inhibition of amorphous calcium phosphate dental nanocomposite. J Biomed Mater Res Part B Appl Biomater 2011; 98: 80-88.

30) Xu HHK, Moreau JL, Sun L, Chow LC. Nanocomposite containing amorphous calcium phosphate nanoparticles for caries inhibition. Dent Mater 2011; 27: 762-769.

31) Moreau JL, Weir MD, Giuseppetti AA, Chow LC, Antonucci JM, Xu HHK. Long-term mechanical durability of dental nanocomposites containing amorphous calcium phosphate nanoparticles. J Biomed Mater Res Part B Appl Biomater 2012; 100: 1264-1273.

32) Zhang F, Allen AJ, Levine LE, Vaudin MD, Skrtic D, Antonucci JM, Hoffman KM, Giuseppetti AA, Ilavsky J. Structural and dynamical studies of acid-mediated conversion in amorphouscalcium-phosphate based dental composites. Dent Mater 2014; 30: 1113-1125.

33) Zhang F, Allen AJ, Levine LE, Espinal L, Antonucci JM, Skrtic D, O'Donnell JN, Ilavsky J. Ultra-small-angle X-ray scattering -X-ray photon correlation spectroscopy studies of incipient structural changes in amorphous calcium phosphate based dental composites. J Biomed Mater Res Part A Appl Biomater 2012; 100: 1293-1306.

34) Langhorst SE, O'Donnell JNR, Skrtic D. In vitro remineralization of enamel by polymeric amorphous calcium phosphate composite: Quantitative micro-radiographic study. Dent Mater 2009; 25: 884-891.

35) Regnault WF, Icenogle TB, Antonucci JM, Skrtic D. Amorphous calcium phosphate/urethane methacrylate resin composites. I. Physicochemical characterization. J Mater Sci Mater Med 2008; 19: 507-515.

36) Lee SY, Regnault WF, Antonucci JM, Skrtic D. Effect of particle size of an amorphous calcium phosphate filler on the mechanical strength and ion release of polymeric composites. J Biomed Mater Res Part B Appl Biomater 2007; 80: 11-17.

37) Skrtic D, Antonucci JM. Effect of chemical structure and composition of the resin phase on vinyl conversion of amorphous calcium phosphate-filled composites. Polym Int 2007; 56: 497-505.

38) Skrtic D, Antonucci J, McDonough W, Liu D. Effect of chemical structure and composition of the resin phase on mechanical strength and vinyl conversion of amorphous calcium phosphate-based composites. J Biomed Mater Res Part A 2004; 68: 763-772.
39) Marović D, Šariri K, Demoli N, Ristić M, Hiller KA, Škrtić D, Rosentritt M, Schmalz G, Tarle Z. Remineralizing amorphous calcium phosphate based composite resins: the influence of inert fillers on monomer conversion, polymerization shrinkage, and microhardness. Croat Med J 2016; 57: 465473.

40) Skrtic D, Antonucci JM, Eanes ED. Improved properties of amorphous calcium phosphate fillers in remineralizing resin composites. Dent Mater 1996; 12: 295-301.

41) Skrtic D, Antonucci JM. Effect of bifunctional comonomers on mechanical strength and water sorption of amorphous calcium phosphate- and silanized glass-filled Bis-GMA-based composites. Biomaterials 2003; 24: 2881-2888.

42) Park MS, Eanes ED, Antonucci JM, Skrtic D. Mechanical properties of bioactive amorphous calcium phosphate/ methacrylate composites. Dent Mater 1998; 14: 137-141.

43) Marovic D, Tarle Z, Hiller KA, Müller R, Ristic M, Rosentritt M, Skrtic D, Schmalz G. Effect of silanized nanosilica addition on remineralizing and mechanical properties of experimental composite materials with amorphous calcium phosphate. Clin Oral Investig 2014; 18: 783-792.

44) Marovic D, Tarle Z, Hiller KA, Müller R, Rosentritt M, Skrtic D, Schmalz G. Reinforcement of experimental composite materials based on amorphous calcium phosphate with inert fillers. Dent Mater 2014; 30: 1052-1060.

45) Cheng L, Weir MD, Xu HHK, Antonucci JM, Kraigsley AM, Lin NJ, Lin-Gibson S, Zhou X. Antibacterial amorphous calcium phosphate nanocomposites with a quaternary ammonium dimethacrylate and silver nanoparticles. Dent Mater 2012; 28: 561-572.

46) Cheng L, Weir MD, Zhang K, Xu SM, Chen Q, Zhou X, Xu HH. Antibacterial nanocomposite with calcium phosphate and quaternary ammonium. J Dent Res 2012; 91: 460-466.

47) Antonucci JM, Fowler BO, Weir MD, Skrtic D, Stansbury JW. Effect of ethyl- $\alpha$-hydroxymethylacrylate on selected properties of copolymers and ACP resin composites. J Mater Sci Mater Med 2008; 19: 3263-3271.

48) O'Donnell JNR, Antonucci JM, Skrtic D. Amorphous calcium phosphate composites with improved mechanical properties. J Bioact Compat Polym 2006; 21: 169-184.

49) O'Donnell JNR, Langhorst SE, Fow MD, Antonucci JM, Skrtic D. Light-cured dimethacrylate-based resins and their composites: comparative study of mechanical strength, water sorption and ion release. J Bioact Compat Polym 2008; 23: 207-226.

50) Skrtic D, Antonucci JM, Eanes ED, Eichmiller FC, Schumacher GE. Physicochemical evaluation of bioactive polymeric composites based on hybrid amorphous calcium phosphates. J Biomed Mater Res 2000; 53: 381-391.

51) Skrtic D, Antonucci JM. Bioactive polymeric composites for tooth mineral regeneration: Physicochemical and cellular aspects. J Funct Biomater 2011; 2: 271-307.

52) Dunn WJ. Shear bond strength of an amorphous calciumphosphate-containing orthodontic resin cement. Am J Orthod Dentofac Orthop 2007; 131: 243-247.

53) Uysal T, Ustdal A, Nur M, Catalbas B. Bond strength of ceramic brackets bonded to enamel with amorphous calcium phosphate-containing orthodontic composite. Eur J Orthod 2010; 32: 281-284.

54) Uysal T, Ulker M, Akdogan G, Ramoglu SI, Yilmaz E. Bond strength of amorphous calcium phosphate-containing orthodontic composite used as a lingual retainer adhesive. Angle Orthod 2009; 79: 117-121.

55) Foster JA, Berzins DW, Bradley TG. Bond strength of an amorphous calcium phosphate-containing orthodontic adhesive. Angle Orthod 2008; 78: 339-344.

56) O'Donnell JNR, Schumacher GE, Antonucci JM, Skrtic D. Adhesion of amorphous calcium phosphate composites bonded to dentin: a study in failure modality. J Biomed Mater Res 
Part B Appl Biomater 2009; 90: 238-249.

57) Cheng L, Weir MD, Limkangwalmongkol P, Hack GD, Xu HHK, Chen Q, Zhou X. Tetracalcium phosphate composite containing quaternary ammonium dimethacrylate with antibacterial properties. J Biomed Mater Res Part B Appl Biomater 2012; 100: 726-734.

58) Zhang K, Cheng L, Weir MD, Bai YX, Xu HHK. Effects of quaternary ammonium chain length on the antibacterial and remineralizing effects of a calcium phosphate nanocomposite. Int J Oral Sci 2016; 8: 45-53.

59) Chow $\mathrm{CKW}, \mathrm{Wu} \mathrm{CD}$, Evans CA. In vitro properties of orthodontic adhesives with fluoride or amorphous calcium phosphate. Int J Dent 2011; 583521.

60) Minick GT, Oesterle LJ, Newman SM, Shellhart WC. Bracket bond strengths of new adhesive systems. Am J Orthodont Dentofac Orthoped 2009; 135: 771-776.

61) Antonucci J, O'Donnell J, Schumacher G, Skrtic D. Amorphous calcium phosphate composites and their effect on compositeadhesive-dentin bonding. J Adhes Sci Technol 2009; 23: 11331147.

62) Zhang L, Weir MD, Chow LC, Antonucci JM, Chen J, Xu HHK. Novel rechargeable calcium phosphate dental nanocomposite. Dent Mater 2016; 32: 285-293.

63) D'Alpino PHP, Silva MS, Vismara MVG, Di Hipólito V, Miranda González AH, de Oliveira Graeff CF. The effect of polymerization mode on monomer conversion, free radical entrapment, and interaction with hydroxyapatite of commercial self-adhesive cements. J Mech Behav Biomed Mater 2015; 46: 83-92.

64) Lezaja M, Veljovic DN, Jokic BM, Cvijovic-Alagic I, Zrilic MM, Miletic V. Effect of hydroxyapatite spheres, whiskers, and nanoparticles on mechanical properties of a model BisGMA/ TEGDMA composite initially and after storage. J Biomed Mater Res Part B Appl Biomater 2013; 101: 1469-1476.

65) Zhang Y, Wu N, Bai X, Xu C, Liu Y, Wang Y. Hydroxyapatite induces spontaneous polymerization of model self-etch dental adhesives. Mater Sci Eng 2013; 33: 3670-3676.

66) Zhang Y, Wang Y. Hydroxyapatite effect on photopolymerization of self-etching adhesives with different aggressiveness. J Dent 2012; 40: 564-570.

67) Katoh Y, Suzuki M, Kato C, Shinkai K, Ogawa M, Yamauchi J. Observation of calcium phosphate powder mixed with an adhesive monomer experimentally developed for direct pulp capping and as a bonding agent. Dent Mater J 2010; 29: 1524.

68) Shinkai K, Taira Y, Suzuki M, Kato C, Ebihara T, Wakaki S, Seki H, Shirono M, Ogisu T, Yamauchi J, Suzuki S, Katoh Y. Dentin bond strength of a new adhesive system containing calcium phosphate experimentally developed for direct pulp capping. Dent Mater J 2009; 28: 743-749.

69) Santos C, Clarke RL, Braden M, Guitian F, Davy KWM. Water absorption characteristics of dental composites incorporating hydroxyapatite filler. Biomaterials 2002; 23: 1897-1904.

70) Santos C, Luklinska ZB, Clarke RL, Davy KW. Hydroxyapatite as a filler for dental composite materials: mechanical properties and in vitro bioactivity of composites. J Mater Sci Mater Med 2001; 12: 565-573.

71) Arcis RW, Lopez-Macipe A, Toledano M, Osorio E, RodriguezClemente R, Murtra J, Fanovich MA, Pascual CD. Mechanical properties of visible light-cured resins reinforced with hydroxyapatite for dental restoration. Dent Mater 2002; 18: 49-57.

72) Labella R, Braden M, Deb S. Novel hydroxyapatite-based dental composites. Biomaterials 1994; 15: 1197-1200.

73) Liu F, Jiang X, Bao S, Wang R, Sun B, Zhu M. Effect of hydroxyapatite whisker surface graft polymerization on water sorption, solubility and bioactivity of the dental resin composite. Mater Sci Eng C 2015; 53: 150-155.

74) Liu F, Wang R, Cheng Y, Jiang X, Zhang Q, Zhu M. Polymer grafted hydroxyapatite whisker as a filler for dental composite resin with enhanced physical and mechanical properties. Mater Sci Eng C 2013; 33: 4994-5000.

75) Liu F, Sun B, Jiang X, Aldeyab SS, Zhang Q, Zhu M. Mechanical properties of dental resin/composite containing urchin-like hydroxyapatite. Dent Mater 2014; 30: 1358-1368.

76) Zhang H, Darvell BW. Failure and behavior in water of hydroxyapatite whisker-reinforced bis-GMA-based resin composites. J Mech Behav Biomed Mater 2012; 10: 39-47.

77) Zhang H, Darvell BW. Mechanical properties of hydroxyapatite whisker-reinforced bis-GMA-based resin composites. Dent Mater 2012; 28: 824-830.

78) Hongquan Z, Ming Z. Effect of surface treatment of hydroxyapatite whiskers on the mechanical properties of bisGMA-based composites. Biomed Mater 2010; 5: 054106.

79) Chen L, Xu C, Wang Y, Shi J, Yu Q, Li H. BisGMA/TEGDMA dental nanocomposites containing glyoxylic acid modified high-aspect ratio hydroxyapatite nanofibers with enhanced dispersion. Biomed Mater 2012; 7: 045014.

80) Chen L, Yu Q, Wang Y, Li H. BisGMA/TEGDMA dental composite containing high aspect-ratio hydroxyapatite nanofibers. Dent Mater 2011; 27: 1187-1195.

81) Zakir M, Al Kheraif AA, Asif M, Wong FS, Rehman IU. A comparison of the mechanical properties of a modified silorane based dental composite with those of commercially available composite material. Dent Mater 2013; 29: e53-e59.

82) Leitune VCB, Collares FM, Trommer RM, Andrioli DG, Bergmann CP, Samuel SMW. The addition of nanostructured hydroxyapatite to an experimental adhesive resin. J Dent 2013; 41: 321-327.

83) Wagner A, Belli R, Stötzel C, Hilpert A, Müller FA, Lohbauer U. Biomimetically-and hydrothermally-grown HAp nanoparticles as reinforcing fillers for dental adhesives. J Adhes Dent 2013; 15: 413-422.

84) Liu WW, He XP, Mo AC, Yao QQ, Ye J, Jing N. Investigation of the mechanical properties of a low-shrinkage liquid crystalline matrix combined with nano-hydroxyapatite. Int $\mathrm{J}$ Nanomed 2011; 6: 1787-1791.

85) Sadat-Shojai M, Atai M, Nodehi A, Khanlar LN. Hydroxyapatite nanorods as novel fillers for improving the properties of dental adhesives: Synthesis and application. Dent Mater 2010; 26: 471-482.

86) Domingo C, Arcis RW, Lopez-Macipe A, Osorio R, RodriguezClemente R, Murtra J, Fanovich MA, Toledano M. Dental composites reinforced with hydroxyapatite: mechanical behavior and absorption/elution characteristics. J Biomed Mater Res 2001; 56: 297-305.

87) Domingo C, Arcis RW, Osorio E, Osorio R, Fanovich MA, Rodriguez-Clemente R, Toledano M. Hydrolytic stability of experimental hydroxyapatite-filled dental composite materials. Dent Mater 2003; 19: 478-486.

88) Akhavan A, Sodagar A, Mojtahedzadeh F, Sodagar K. Investigating the effect of incorporating nanosilver/ nanohydroxyapatite particles on the shear bond strength of orthodontic adhesives. Acta Odontol Scand 2013; 71: 10381042.

89) Calabrese L, Fabiano F, Currò M, Borsellino C, Bonaccorsi L, Fabiano V, Ientile R, Proverbio E. Hydroxyapatite whiskers based resin composite versus commercial dental composites: mechanical and biocompatibility characterization. Adv Mater Sci Eng 2016; 2172365.

90) Lung CYK, Sarfraz Z, Habib A, Khan AS, Matinlinna JP. Effect of silanization of hydroxyapatite fillers on physical and mechanical properties of a bis-GMA based resin composite. J Mech Behav Biomed Mater 2016; 54: 283-294.

91) Chadda H, Naveen SV, Mohan S, Satapathy BK, Ray AR, Kamarul T. Cytotoxic evaluation of hydroxyapatite-filled and silica/hydroxyapatite-filled acrylate-based restorative composite resins: An in vitro study. J Prosthet Dent 2016; 
116: $129-135$.

92) Tezvergil-Mutluay A, Seseogullari-Dirihan R, Feitosa VP, Cama G, Brauer DS, Sauro S. Effects of composites containing bioactive glasses on demineralized dentin. J Dent Res 2017; 96: 999-1005.

93) Rizk M, Hohlfeld L, Thanh LT, Biehl R, Luhmann N, Mohn D, Wiegand A. Bioactivity and properties of a dental adhesive functionalized with polyhedral oligomeric silsesquioxanes (POSS) and bioactive glass. Dent Mater 2017; 33: 1056-1065.

94) Hyun HK, Ferracane JL. Influence of biofilm formation on the optical properties of novel bioactive glass-containing composites. Dent Mater 2016; 32: 1144-1151.

95) Hyun HK, Salehi S, Ferracane JL. Biofilm formation affects surface properties of novel bioactive glass-containing composites. Dent Mater 2015; 31: 1599-1608.

96) Khvostenko D, Hilton TJ, Ferracane JL, Mitchell JC, Kruzic JJ. Bioactive glass fillers reduce bacterial penetration into marginal gaps for composite restorations. Dent Mater 2016; 32: 73-81.

97) Korkut E, Torlak E, Altunsoy M. Antimicrobial and mechanical properties of dental resin composite containing bioactive glass. J Appl Biomater Funct Mater 2016; 14: e296301.

98) Salehi S, Gwinner F, Mitchell JC, Pfeifer C, Ferracane JL. Cytotoxicity of resin composites containing bioactive glass fillers. Dent Mater 2015; 31: 195-203.

99) Kohda N, Iijima M, Kawaguchi K, Toshima H, Muguruma T, Endo K, Mizoguchi I. Inhibition of enamel demineralization and bond-strength properties of bioactive glass containing 4-META/MMA-TBB-based resin adhesive. Eur J Oral Sci 2015; 123: 202-207.

100) Tauböck TT, Zehnder M, Schweizer T, Stark WJ, Attin T, Mohn D. Functionalizing a dentin bonding resin to become bioactive. Dent Mater 2014; 30: 868-875.

101) Osorio R, Yamauti M, Sauro S, Watson TF, Toledano M. Zinc incorporation improves biological activity of beta-tricalcium silicate resin-based cement. J Endod 2014; 40: 1840-1845.

102) Osorio R, Yamauti M, Sauro S, Watson TF, Toledano M. Experimental resin cements containing bioactive fillers reduce matrix metalloproteinase-mediated dentin collagen degradation. J Endod 2012; 38: 1227-1232.

103) Profeta AC, Mannocci F, Foxton RM, Thompson I, Watson TF, Sauro S. Bioactive effects of a calcium/sodium phosphosilicate on the resin-dentine interface: a microtensile bond strength, scanning electron microscopy, and confocal microscopy study. Eur J Oral Sci 2012; 120: 353-362.

104) Profeta AC. Preparation and properties of calcium-silicate filled resins for dental restoration. Part II: Micro-mechanical behaviour to primed mineral-depleted dentine. Acta Odontol Scand 2014; 72: 607-617.

105) Khvostenko D, Mitchell JC, Hilton TJ, Ferracane JL, Kruzic JJ. Mechanical performance of novel bioactive glass containing dental restorative composites. Dent Mater 2013; 29: $1139-1148$.

106) Manfred L, Covell DA, Crowe JJ, Tufekci E, Mitchell JC. A novel biomimetic orthodontic bonding agent helps prevent white spot lesions adjacent to brackets. Angle Orthod 2013; 83: 97-103.

107) Sauro S, Osorio R, Watson TF, Toledano M. Therapeutic effects of novel resin bonding systems containing bioactive glasses on mineral-depleted areas within the bonded-dentine interface. J Mater Sci Mater Med 2012; 23: 1521-1532.

108) Brown ML, Davis HB, Tufekci E, Crowe JJ, Covell DA, Mitchell JC. Ion release from a novel orthodontic resin bonding agent for the reduction and/or prevention of white spot lesions. Angle Orthod 2011; 81: 1014-1020.

109) Carneiro KK, Meier MM, Santos CC, Maciel AP, Carvalho $\mathrm{CN}$, Bauer J. Adhesives doped with bioactive niobophosphate micro-filler: degree of conversion and microtensile bond strength. Braz Dent J 2016; 27: 705-711.

110) Chatzistavrou X, Velamakanni S, DiRenzo K, Lefkelidou A, Fenno JC, Kasuga T, Boccaccini AR, Papagerakis P. Designing dental composites with bioactive and bactericidal properties. Mater Sci Eng C 2015; 52: 267-272.

111) Davis HB, Gwinner F, Mitchell JC, Ferracane JL. Ion release from, and fluoride recharge of a composite with a fluoridecontaining bioactive glass. Dent Mater 2014; 30: 1187-1194.

112) Xu HHK, Sun L, Weir MD, Takagi S, Chow LC, Hockey B. Effects of incorporating nanosized calcium phosphate particles on properties of Whisker-reinforced dental composites. J Biomed Mater Res. Part B Appl Biomater 2007; 81: 116-125.

113) Xu HHK, Sun L, Weir MD, Antonucci JM, Takagi S, Chow LC, Peltz M. Nano DCPA-Whisker composites with high strength and Ca and PO(4) release. J Dent Res 2006; 85: 722727.

114) Xu HHK, Weir MD, Sun L. Nanocomposites with Ca and $\mathrm{PO}(4)$ release: Effects of reinforcement, dicalcium phosphate particle size and silanization. Dent Mater 2007; 23: 14821491.

115) Xu HHK, Weir MD, Sun L, Takagi S, Chow LC. Effects of calcium phosphate nanoparticles on Ca-PO(4) composite. J Dent Res 2007; 86: 378-383.

116) Mehdawi IM, Pratten J, Spratt DA, Knowles JC, Young AM. High strength re-mineralizing, antibacterial dental composites with reactive calcium phosphates. Dent Mater 2013; 29: 473-484.

117) Mehdawi I, Neel EA, Valappil SP, Palmer G, Salih V, Pratten J, Spratt DA, Young AM. Development of remineralizing, antibacterial dental materials. Acta Biomater 2009; 5: 25252539.

118) Panpisut P, Liaqat S, Zacharaki E, Xia W, Petridis H, Young AM. Dental composites with calcium/strontium phosphates and polylysine. PLoS One 2016; 11: e0164653.

119) Dickens-Venz SH, Takagi S, Chow LC, Bowen RL, Johnston $\mathrm{AD}$, Dickens B. Physical and chemical properties of resinreinforced calcium phosphate cements. Dent Mater 1994; 10: 100-106.

120) Zhang K, Zhang N, Weir MD, Reynolds MA, Bai Y, Xu HHK. Bioactive dental composites and bonding agents having remineralizing and antibacterial characteristics. Dent Clin North Am 2017; 61: 669-687.

121) Zmener O, Pameijer CH, Hernandez S. Resistance against bacterial leakage of four luting agents used for cementation of complete cast crowns. Am J Dent 2014; 27: 51-55.

122) Pameijer CH, Garcia-Godoy F, Morrow BR, Jefferies SR. Flexural strength and flexural fatigue properties of resinmodified glass ionomers. J Clin Dent 2015; 26: 23-27.

123) Bansal R, Burgess J, Lawson NC. Wear of an enhanced resinmodified glass-ionomer restorative material. Am J Dent 2016; 29: 171-174.

124) Alkhudhairy FI, Ahmad ZH. Comparison of shear bond strength and microleakage of various bulk-fill bioactive dentin substitutes: An in vitro Study. J Contemp Dent Pract 2016; 17: 997-1002.

125) Jun SK, Lee JH. The Biomineralization of a bioactive glassincorporated light-curable pulp capping material using human dental pulp stem cells. Biomed Res Int 2017; 2495282.

126) Croll TP, Berg JH, Donly KJ. Dental repair material: a resinmodified glass-ionomer bioactive ionic resin-based composite. Compend Contin Educ Dent Suppl 2015; 36: 60-65.

127) May E, Donly KJ. Fluoride release and re-release from a bioactive restorative material. Am J Dent 2017; 30: 305-308.

128) Alrahlah A. Diametral tensile strength, flexural strength, and surface microhardness of bioactive bulk fill restorative. J Contemp Dent Pract 2018; 19: 13-19.

129) Garoushi S, Vallittu PK, Lassila L. Characterization of fluoride releasing restorative dental materials. Dent Mater J 2018; 37: 293-300. 
130) Dorozhkin SV. Calcium orthophosphates as bioceramics: state of the art. J Funct Biomater 2010; 1: 22-107.

131) Widstrom E, Birn H, Haugejorden O, Sundberg H. Fear of amalgam: dentists' experiences in the Nordic countries. Int Dent J 1992; 42: 65-70.

132) Moszner N, Salz U. New developments of polymeric dental composites. Prog Polym Sci 2001; 26: 535-576.

133) Kantharia N, Naik S, Apte S, Kheur M, Kheur S, Kale B. Nano-hydroxyapatite and its contemporary applications. Bone 2014; 34: 1-71.

134) Vallet-Regi M, González-Calbet JM. Calcium phosphates as substitution of bone tissues. Prog Sol Stat Chem 2004; 32: 1-31.

135) Fanovich M, Castro M, Lopez JP. Structural analysis of modified hydroxyapatite powders. Mater Res Bull 2001; 36: 487-496.

136) Huang W, Day DE, Kittiratanapiboon K, Rahaman MN. Kinetics and mechanisms of the conversion of silicate (45S5), borate, and borosilicate glasses to hydroxyapatite in dilute phosphate solutions. J Mater Sci Mater Med 2006; 17: 583596.

137) Rahaman MN, Day DE, Sonny Bal B, Fu Q, Jung SB, Bonewald LF, Tomsia AP. Bioactive glass in tissue engineering. Acta Biomater 2011; 7: 2355-2373.

138) Koutsopoulos S. Synthesis and characterization of hydroxyapatite crystals: a review study on the analytical methods. J Biomed Mater Res Part A 2002; 62: 600-612.

139) LeGeros R, Lin S, Rohanizadeh R, Mijares D, LeGeros J. Biphasic calcium phosphate bioceramics: preparation, properties and applications. J Mater Sci Mater Med 2003; 14: 201-209.

140) Bouyer E, Gitzhofer F, Boulos M. Morphological study of hydroxyapatite nanocrystal suspension. J Mater Sci Mater Med 2000; 11: 523-531.

141) Zanotto A, Saladino ML, Martino DC, Caponetti E. Influence of temperature on calcium hydroxyapatite nanopowders. Adv Nanopart 2012; 1: 1-8.

142) Cadenaro M, Breschi L, Rueggeberg FA, Suchko M, Grodin E, Agee K, Di Lenarda R, Tay FR, Pashley DH. Effects of residual ethanol on the rate and degree of conversion of five experimental resins. Dent Mater 2009; 25: 621-628.

143) Al-Sanabani JS, Madfa AA, Al-Sanabani FA. Application of calcium phosphate materials in dentistry. Int $\mathrm{J}$ Biomater 2013; 876132

144) Dorozhkin SV. Medical application of calcium orthophosphate bioceramics. Bio 2011; 1: 1-51.

145) Tsuji T, Onuma K, Yamamoto A, Iijima M, Shiba K. Direct transformation from amorphous to crystalline calcium phosphate facilitated by motif-programmed artificial proteins. Pro Nat Acad Sci USA 2008; 105: 16866-16870.

146) Frencken JE, Peters MC, Manton DJ, Leal SC, Gordan VV, Eden E. Minimal Intervention Dentistry (MID) for managing dental caries - a review: Report of a FDI task group. Int Dent J 2012; 62: 223-243.

147) Melo M, Weir M, Passos V, Powers M, Xu H. pH-activatable nano-amorphous calcium phosphate to reduce dental enamel demineralization. Dent Mater 2016; 32: e64.

148) Zero DT. Recaldent ${ }^{\mathrm{TM}}$ - evidence for clinical activity. Adv Dent Res 2009; 21: 30-34.

149) Zhao J, Liu Y, Sun W-b, Zhang H. Amorphous calcium phosphate and its application in dentistry. Chem Cent $J$ 2011; 5: 40.
150) $\mathrm{Xu} \mathrm{H.} \mathrm{Dental} \mathrm{composites} \mathrm{comprising} \mathrm{nanoparticles} \mathrm{of}$ amorphous calcium phosphate. Google Patents; 2014.

151) Skrtic D, Antonucci JM. Dental composites: bioactive polymeric amorphous calcium phosphate-based. Encycl Biomed Polym Polym Biomater 2015: 2443-2462.

152) Peng H, Wang J, Lv S, Wen J, Chen J-F. Synthesis and characterization of hydroxyapatite nanoparticles prepared by a high-gravity precipitation method. Ceram Int 2015; 41: 14340-14349.

153) Hernandez SER, Streeter I, de Leeuw NH. The effect of water on the binding of glycosaminoglycan saccharides to hydroxyapatite surfaces: a molecular dynamics study. Phys Chem Chem Phys 2015; 17: 22377-22388.

154) Khan AS, Aziz MS, Paul D, Wong F, Rehman IU. Synthesis and in-vitro analysis of degradative resistance of a novel bioactive composite. J Bionanosci 2008; 2: 75-88.

155) Orlovskii V, Komlev V, Barinov S. Hydroxyapatite and hydroxyapatite-based ceramics. Inorg Mater 2002; 38: 973984.

156) Williams D. The science and applications of biomaterials. Int J Mater Prod Technol 1995; 10: 360-377.

157) Hench LL. Introduction to bioceramics. Adv Ser Ceram 1993; 1: $1-24$.

158) Suchanek W, Yoshimura M. Processing and properties of hydroxyapatite-based biomaterials for use as hard tissue replacement implants. J Mater Res 1998; 13: 94-117.

159) Hing KA, Best SM, Bonfield W. Characterization of porous hydroxyapatite. J Mater Sci Mater Med 1999; 10: 135-145.

160) Ślósarczyk A, Stobierska E, Paszkiewicz Z. Porous hydroxyapatite ceramics. J Mater Sci Lett 1999; 18: 11631165.

161) Ambard AJ, Mueninghoff L. Calcium phosphate cement: review of mechanical and biological properties. J Prosth 2006; 15: 321-328.

162) Khalid H, Syed M, Iqbal H, Rehman I, Khan A. Monomer leaching and degree of conversion of bioactive dental composites. Dent Mater 2016; 32: e61-e62.

163) Tsai HC, Li YC, Young TH, Chen MH. Novel microinjector for carrying bone substitutes for bone regeneration in periodontal diseases. J Formos Med Assoc 2016; 115: 45-50.

164) Ogawa K, Miyaji H, Kato A, Kosen Y, Momose T, Yoshida T, Nishida E, Miyata S, Murakami S, Takita H. Periodontal tissue engineering by nano beta-tricalcium phosphate scaffold and fibroblast growth factor-2 in one-wall infrabony defects of dogs. J Periodontal Res 2016; 51: 758-767.

165) Deng Y, Jiang C, Li C, Li T, Peng M, Wang J, Dai K. 3D printed scaffolds of calcium silicate-doped beta-TCP synergize with co-cultured endothelial and stromal cells to promote vascularization and bone formation. Sci Rep 2017; 7: 5588 .

166) Shah AT, Ain Q, Chaudhry AA, Ahmad S, Zarif F, Siddiqi SA, Qasim Sb, Görke O, Khan AS, Rehman Iu. Acid catalysed synthesis of bioactive glass by evaporation induced self assembly method. J Non-Cryst Sol 2018; 479: 1-8.

167) Shah AT, Batool M, Chaudhry AA, Iqbal F, Javaid A, Zahid S, Ilyas K, bin Qasim S, Khan AF, Khan AS, Rehman Iu. Effect of calcium hydroxide on mechanical strength and biological properties of bioactive glass. J Mechan Behav Biomed Mater 2016; 61: 617-626.

168) Malkondu O, Karapinar Kazandag M, Kazazoglu E. A review on biodentine, a contemporary dentine replacement and repair material. BioMed Res Int 2014; 160951. 